\title{
APLIKASI AJARAN SOLIDARITAS KRISTEN BERDASARKAN ALKITAB PADA GEREJA KEMAH INJIL INDONESIA KOTA KUPANG NUSA TENGGARA TIMUR
}

\author{
Yunus Laukapitang \\ nus_lau@yahoo.com \\ Daniel Ronda \\ danielronda@ymail.com
}

\begin{abstract}
ABSTRAK
Sesuai dengan permasalahan yang ada, maka tujuan penulisan karya ilmiah ini adalah: Pertama, untuk menjelaskan pemahaman konsep ajaran solidaritas kristen secara teologis. Kedua, untuk mengetahui sejauh mana pemahaman konsep ajaran teologi solidaritas Kristen diaplikasikan pada Gereja Kemah Injil Indonesia Kota Kupang.

Dalam penulisan karya ilmiah ini, penulis menggunakan metode penelitian yaitu: Penulis memperoleh data melalui penelitian kepustakaan, dan penelitian lapangan. Dalam penelitian lapangan data diperoleh melalui teknik observasi langsung, wawancara, questioner dan data dari dokumen-dokumen gereja yang diperoleh selama kegiatan penelitian.

Berdasarkan hasil uraian penulis dalam karya ilmiah mengenai aplikasi ajaran solidaritas kristen berdasarkan alkitab pada Gereja Kemah Injil Indonesia kota Kupang Nusa Tenggara Timur, maka penulis dapat menarik kesimpulan sebagai berikut: Pertama, dalam pelaksanaan solidaritasnya, gereja harus melaksanakan dalam konsepsi alkitabiah yang benar, yakni: didasarkan atas sifat Allah sendiri, yang adalah kasih dan berlas kasihan terhadap penderitaan umat manusia. Kedua, dalam pelaksanaan solidaritasnya, gereja perlu melihat kepada wujud solidaritasnya, gereja perlu melihat kepada wujud solidaritas Kristen yang telah diberikan oleh Kristus, jemaat mula-mula dan rasul Paulus. Ketiga, dalam merefleksikan konsep solidaritas Kristen bagi pelayanan masa kini dalam konteks Indonesia secara umum dan GKII Kota Kupang secara khusus dapat dilaksanakan dalam bentuk solidaritas trasformatif, misiologis, inkarnatif dan solidaritas holistik.
\end{abstract}

Kata Kunci: Aplikasi, solidaritas, Kristen, Kupang 


\section{PENDAHULUAN}

\section{Latar Belakang Masalah}

Dunia saat ini ditandai oleh kemajuan diberbagai bidang kehidupan, yang dikenal dengan istilah era globalisasi dan informasi. Kemajuan ini membawa perubahan dalam seluruh bidang kehidupan manusia baik informasi, transportasi, cara pandang kepada Allah, dunia dan sesama manusia. Secara negatif perubahan ini dicirikan oleh materialisme, individualisme dan hedonisme, yang mana praktika kehidupan ditandai oleh kasih, solidaritas atau kebersamaan yang dinyatakan melalui tindakan nyata untuk menolong orang lain yang mengalami berbagai penderitaan baik secara jasmani dan rohani semakin hilang. Tim keadilan, Perdamaian dan Ciptaan Gereja-Gereja se-Dunia menujukkan mengenai kondisi dunia saat ini dengan menyebutkan:

Pada tahun 2003, ada 7,7 juta orang memiliki kekayaan senilai 1 juta dolas AS atau lebih. Jumlah kekayaan mereka ini mencapai 28.9 triliun dollar AS, atau hamper tiga kali lipat produksi nasional AS pada tahun yang sama. Pada saat yang sama, 840 juta orang di seantero dunia kekurangan pangan dan 1,5 milyar - yang kebanyakan adalah perempuan, anak-anak dan penduduk asli hidup dengan kurang dari 1 dollar AS per hari... Konsumsi barang dan jasa 20\% orang-orang terkaya dunia setara dengan $86 \%$ konsumsi global. Penghasilan tahunan dari orang-orang terkaya yang berjumlah $1 \%$ sama dengan penghasilan orang-orang termiskin yang berjumlah 57\%, dan paling sedikit 24. 000 orang meninggal setiap hari karena kemiskinan dan kurang gizi. Masalah-masalah lingkungan hidup - pemanasan global, penipisan sumber daya alam, dan hilangnya keanekaragaman hayati semakin parah saja. Sebagai contoh, kita akan ke-hilangan 30-70 persen dari keanekara-gaman hayati dunia dalam kurun waktu 2030 tahun ke depan. Perang berkecam-buk di banyak bagian dunia, militerisme dan keke-rasan telah menjadi bagian kehidupan kita sehari-hari. Krisis keuangan semakin sering dan lebih intens. Pengangguran semakin merajalela, mengancam mata pen-carian orang banyak. Dengan kata lain, kehidupan manusia dan bumi sudah sangat terancam. ${ }^{1}$

\footnotetext{
${ }^{1}$ Tim Keadilan, Perdamaian dan Ciptaan Dewan Gereja-gereja se-Dunia (DGD) Jenewa, 2006. Globalisasi Alternatif Mengutamakan Rakyat dan Bumi Sebu-ah Dokumen Latar belakang.(Jakarta: PMK HKBP), 3-4
} 
Agama Kristen di tengah keadaan dunia yang demikian inilah ditantang untuk menunjukkan identitas sebagai agama yang didasarkan oleh kasih, yang diwujudnyatakan melalui sikap menolong mereka yang miskin, menentang ketidakadilan dan menyuarakan hak-hak kaum lemah, yang tertindas dan yang dilecehkan secara sosial. W. N. Natsir Silalahi menulis: "Gereja terpanggil untuk berbicara, bertindak dan campur tangan, berpi-hak kepada si lemah, menolak ketidakadilan, ketidakbenaran dan penindasan sebagai ma-nifestasi kesaksian dan pelayanan serta mengekspresikan dirinya di tengah-tengah dunia ini. ${ }^{2}$ Dengan keterlibatan ini, gereja dapat menunjukkan solidaritasnya secara nyata

Kristus dalam pelayanan-Nya selama di dunia, telah menyatakan solidaritas-Nya secara nyata dengan orang-orang yang mengalami berbagai masalah baik secara jasmani dan rohani. Ini juga ditunjukkan oleh jemaat mula-mula di Yerusalem, dengan menolong sesama anggota jemaat yang mengalami kekurangan. Rasul Paulus juga menunjukkan hal yang sama, dengan memberikan bantuan keuangan yang di-perolehnya dari jemaat-jemaat di luar kota Yerusalem untuk menolong anggotaanggota jemaat di Yerusalem yang mengalami penderitaan. Rasul Paulus menyebutkan dalam Galatia 2:10, " Hanya kami harus tetap mengingat orang-orang miskin dan memang itulah yang sungguh-sungguh $\mathrm{ku}$ usahakan melakukannya." Ini menunjukkan bahwa bagi rasul Paulus, pelayanan solidaritas bagi orang miskin merupakan bagian yang tidak terlepas dari pelayanan pekabaran Injil.

Jika solidaritas ini, dikaitkan dengan konteks Indonesia dengan penduduk miskin pada tahun 2009, mengacu data BPS, penduduk hampir miskin berjumlah 20,66 juta atau 8,99 persen dari total penduduk Indonesia. Pada tahun 2010, jumlah bertambah menjadi 22,9 juta jiwa atau 9,88 persen dari total penduduk Indonesia. Pada tahun 2011, jumlahnya bertambah 5 juta jiwa sehingga menjadi total 27,12 juta jiwa atau 10,28 persen total penduduk. Jumlah penduduk Indonesia berdasarkan sensus penduduk tahun 2010 adalah 237.556 .363 jiwa. $^{3}$ Lebih lanjut mengenai kondisi kemiskinan yang ada di Indonesia data BPS dan bank Dunia menunjukkan: ${ }^{4}$

\begin{tabular}{|l|l|l|}
\hline TAHUN & BPS & BANK DUNIA \\
\hline
\end{tabular}

${ }^{2}$ W.N. Natsir Silalahi, "Gereja, Visi dan Missinya”. Refleksi (No. 10 Desember 1989), 14.

${ }^{3}$ Kompas, Jumat 16 September 2011 , 17. 5 juta hampir Miskin Pemerintah Pastikan Harga BBM Bersubsidi Tidak Naik. kemiskinan.

${ }^{4}$ Kompas Jumat 16 September 2011, 46 Penyaluran anggaran Jangan politisasi dana 


\begin{tabular}{|c|c|c|c|c|c|c|}
\hline & \multicolumn{2}{|c|}{$\begin{array}{c}\text { JUMLAH } \\
\text { PENDUDUK } \\
\text { MISKIN }\end{array}$} & \multicolumn{2}{c|}{$\begin{array}{c}\text { PENDUDUK } \\
\text { MISKIN } \\
\text { DI BAWAH 1 } \\
\text { DOLLAR AS PP }\end{array}$} & \multicolumn{2}{c|}{$\begin{array}{c}\text { PENDUDUK MISKIN } \\
\text { DI BAWAH 2 } \\
\text { DOLLAR AS PP }\end{array}$} \\
\cline { 2 - 7 } & JUTA & PERSEN & JUTA & PERSEN & JUTA & PERSEN \\
\hline 1996 & 34,01 & 17,47 & 15,40 & 7,80 & 99,60 & 50,50 \\
\hline 1998 & 49,50 & 24,23 & - & - & - & - \\
\hline 1999 & 47,97 & 23,43 & 24,90 & 12,00 & 135,00 & 65,10 \\
\hline 2000 & 38,70 & 19,14 & 20,90 & 9,90 & 125,30 & 59,50 \\
\hline 2001 & 37,90 & 18,41 & 19,70 & 9,20 & 125,20 & 58,70 \\
\hline 2002 & 38,40 & 18,20 & 15,50 & 7,20 & 115,60 & 53,50 \\
\hline 2003 & 37,30 & 17,42 & 14,50 & 6,60 & 110,00 & 50,10 \\
\hline 2004 & 36,10 & 16,66 & 16,50 & 7,40 & 109,10 & 49,00 \\
\hline 2005 & 35,10 & 15,97 & 13,60 & 6,00 & 102,10 & 45,20 \\
\hline 2006 & 39,30 & 17,75 & 19,50 & 8,50 & 113,80 & 49,60 \\
\hline 2007 & 37,17 & 16,58 & 15,50 & 6,70 & 105,30 & 45,20 \\
\hline 2008 & 34,96 & 15,42 & 14,00 & 5,90 & 100,70 & 42,60 \\
\hline 2009 & 32,53 & 14,15 & - & - & - & - \\
\hline 2010 & 31,02 & 13,33 & - & - & - & - \\
\hline 2011 & 30,02 & 12,49 & & & & \\
\hline
\end{tabular}

Sumber Bappenas: Data makro kemiskinan

\begin{tabular}{|l|l|l|l|l|l|l|}
\hline $\begin{array}{l}\text { Indikator } \\
\text { Pembangunan }\end{array}$ & 2005 & \multicolumn{1}{|c|}{2006} & 2007 & 2008 & 2009 & $\begin{array}{c}2010 \\
\text { APBN-P }\end{array}$ \\
\hline Pertumbuhan & 5,7 & 5,5 & 6,3 & 6,3 & 4,3 & 5,8 \\
\hline Inflasi & 17,1 & 6,6 & 6,6 & 12,5 & 6,2 & 5,3 \\
\hline Kemiskinan & 15,97 & 17,75 & 16,58 & 15,42 & 14,15 & 13,33 \\
\hline
\end{tabular}

Keadaan yang terjadi secara nasional ini jelas mempunyai kesamaan dengan Propinsi Nusa Tenggara Timur yang menjadi propinsi yang juga mempunyai tingkat penduduk miskin besar di Indonesia yang tidak dapat disangkal sebagai daerah kantong Kristen. Mengenai Propinsi Nusa Tenggara Timur data dari sumber data BPS 2010, Riskesdas diperoleh tentang gambaran masyarakat NTT antara lain: ${ }^{5}$

- Penduduk : 4.619. 655 jiwa

- 22 kabupaten/kota

- Kepadatan: 95 jiwa/km2 - terbesar Kota Kupang (1l.44l jiwa/km2) dan terendah di Sumba Timur dan Sumba Tengah (33 jiwa/km2)

- Provinsi ke-5 dengan angka kemiskinan tertinggi (23,30\%)

\footnotetext{
${ }^{5}$ Mesakh A. P. Dethan, Orasi Ilmiah pada Dies Natalis dan Wisuda STTIK Kupang, 19 Agustus 2011.
} 
- Angka kematian bayi : 31, 2/ 1000

- $58,4 \%$ balita pendek (stunting)

- 13,2 Balita malnutrisi akut

- Lebih $60 \%$ anak mengalami anemia

- $50 \%$ anak usia sekolah menderita cacingan

- Indeks pertumbuhan manusia: 66,15 (peringkat 31 dari 33 provinsi)

- Tingkat melek huruf: 90,24 (laki-laki) dan 85,85 (perempuan)

- Pendapatan per kapita penduduk : 4,89 juta/tahun (tertinggi penduduk kota Kupang 11,59 juta/tahun. Terendah Sumba Barat Daya 2, 89 juta/-tahun

Secara khusus untuk kota Kupang, " profil kemiskinan Kota Kupang tahun 2007 terdapat 23. 472 Rumah Tangga Miskin yang dapat diamati dalam sudut pandang harga mutlak dan jumlah rill rumah tangga miskin maupun menurut menurut harga relatif atau prosentasi miskin dari total jumlah rumah tangga sebanyak 61. 728." ${ }^{6}$ Lebih lanjut dijelaskan, "penurunan prosentasi Rumah Tangga Miskin (RTM) 15\% pertahun dengan titik star 23. 472 (keadaan 2007) senantiasa mengalami pergerakan yang signifikan yang diperkirakan tahun 2010 berada pada angka 14. 242 RTM". $^{7}$

Apa yang dapat dilakukan oleh gereja-gereja di Indonesia saat ini, A.A. Yewangoe, menulis:

Jadi gereja-gereja di Indonesia merasa bahwa tugas mereka adalah memperlihatkan solidaritas dengan kaum miskin, seperti Krisitus sendiri menunjukkan solidaritas-Nya dalam sejarah manusia. Apa arti keadilan yang sesungguhnya melalui penderitaan-Nya, Ia selalu berdiri pada pihak yang tertindas, yang miskin dan kesepiaan ... jadi solidaritas dengan kaum miskin adalah kata kunci gereja di Indonesia. $^{8}$

Namun solidaritas gereja di Indonesia bukan hanya untuk orang yang miskin, tetapi men-cakup orang yang lemah, tertindas, dilecehkan secara sosial, menyuarakan keadilan dan kebenaran dan menegakkan hak-hak asasi manusia, kesamaan gender, pendidikan yang berkualitas, kesehatan, dan lingkungan hidup yang juga merupakan agenda dari

\footnotetext{
${ }^{6}$ Humas dan Protokol Sekretariat Daerah Kota Kupang. Sosok dan Pemikiran Bagi Kesejahteraan Rakyat: Drs. Daniel Adoe. Walikota Kupang 2007-2012. (Kupang:Karya Guna Kupang, 2011), 91.

${ }^{7}$ Ibid., 226.

${ }^{8}$ A.A. Yewangoe, Theologia Crusis Di Asia (Jakarta:BPK Gunung Mulia, 1989), 276.
} 
tujuan pembangunan millenium. Mengenai agenda tersebut Obertina Modesta Johanis, menulis:

Pada tahun 2015, kemiskinan dan kelaparan yang parah ditargetkan dapat dihapuskan. Pernyataan ini merupakan komitmen pertama dari pemimpin 188 negara (termasuk Indonesia di dalamnya) yang berkumpul dalam sebuah forum yang disebut Millenium Summit pada tahun 2000. Komitmen di atas merupakan satu dari delapan tujuan yang dikenal sebagai Millenium Developments Goals (MDGs). Delapan tujuan tersebut adalah:

1. Memberantas kemiskinan dan kelaparan

2. Mencapai pendidikan dasar universal

3. Meningkatkan kesetaraan gender dan memberdayakan perempuan

4. Menurunkan angka kematian anak

5. Meningkatkan kesehatan ibu

6. Memerangani HIV/AIDS, malaria, dan penyakit lainnya

7. Menjamin kelestarian lingkungan

8. Mengembangkan Kemitraan global untuk pembagunan. ${ }^{9}$

Dengan melihat kenyataan di atas, bahwa Tuhan Yesus, Rasul Paulus dan jemaat mula-mula turut menyatakan solidaritas dengan mereka yang mengalami penderitaan baik secara jasmani dan rohani. Namun kenyataan teladan ini tidak dilaksanakan sepenunhnya oleh gereja-gereja di Indonesia. Ini nyata dengan adanya gereja yang tidak peduli dengan masalah-masalah sosial, politik dan ekonomi yang ada.

Berdasarkan latar belakang adanya kondisi nyata dan pemahaman teologi yang berkembang inilah penulis mengambil judul, aplikasi teologi solidaritas Kristen berdasasrkan Alkitab pada Gereja Kemah Injil Kota Kupang Nusa Tenggara Timur, sebagai sampel untuk melihat sejauh mana aplikasi pelaksanaan teologi ini dalam Gereja Kemah Injil Daerah Kupang-Nusa Tenggara Timur.

\section{Pokok Masalah}

Berdasarkan latar belakang masalah yang telah dijelaskan, maka dalam pembahasan karya ilmiah ini, pokok masalah yang coba dijelaskan penulis yakni, apa konsep ajaran solidaritas Kristen ? dan bagamana konsep ajaran solidaritas Kristen diaplikasikan pada Gereja Kemah Injil Indonesia Kota Kupang?

\footnotetext{
${ }^{9}$ Obertina Modesta Johanis. “Gereja Kaum (perempuan) Miskin”. Merentang Sejarah Memaknai Kemandirian Menjadi gereja bagi sesama oleh Majelis Sinode Gereja Kristen Pasundan (Jakarta:Mejelis Sinode Gereja Kristen Pasudan \& BPK. Gunung Mulia , 2009), 111-112.
} 


\section{Tujuan Penelitian}

Dari penelitian karya ilmiah ini, tujuan yang diharapkan peneliti, yakni: Pertama, untuk menjelaskan pemahaman konsep ajaran solidaritas kristen secara teologis. Kedua, untuk mengetahui sejauh mana pemahaman konsep ajaran teologi solidaritas Kristen diaplikasikan pada Gereja Kemah Injil Indonesia Kota Kupang.

\section{Manfaat Penulisan}

Dari penulisan karya ilmiah ini, manfaat yang diharapkan:

Pertama, dapat memberikan masukan-masukan yang baik bagi gereja untuk mewujudkan solidaritas Kristen secara nyata bagi masyarakat.

Kedua, dapat dipakai sebagai bahan untuk seminar mengenai ajaran teologi solidaritas Kristen dalam pelayanan gereja masa kini.

Ketiga, dapat memperkaya pembaca mengenai ajaran solidaritas Kristen secara teologi sehingga dalam pelaksanaannya di tengah kehidupan bermasyarakat tidak menyimpang dari kebenaran firman Tuhan, dan dapat dipakai sebagai bahan acuan dalam pelaksanaan program pelayanan bagi gereja lokal, secara khusus Gereja Kemah Injil Indonesia Derah Kupang-Nusa Tenggara Timur.

\section{Metode Penelitian}

Dalam penulisan karya ilmiah ini, metode penelitian yang dipakai adalah metode penelitian deskriptif kuantitatif. Penulis memperoleh data melalui penelitian kepustakaan, dan penelitian lapangan. Dalam penelitian lapangan data diperoleh melalui teknik observasi langsung, wawancara, questioner dalam bentuk pertanyaan baik terbuka dan tertutup serta dokumen-dokumen gereja yang diperoleh selama kegiatan penelitian.

\section{Batasan Penulisan}

Penulis menyadari betapa banyaknya pembahasan mengenai solidaritas dalam ber-bagai disiplin ilmu, maka dalam penulisan karya ilmiah ini, penulis membatasi pembahasan teologi solidaritas Kristen dalam pembahasan lebih banyak berfokus pada Perjanjian Baru.

\section{Defenisi-defenisi}

\section{Solidaritas}

Secara etimoligis, solidaritas, dalam Kamus Besar Bahasa Indonesia berarti, "sifat (perasaan) solider; sifat satu rasa (senasib); perasaan setia 
kawan." 10 Pengertian ini juga diperluas dalam pemahaman yang dihubungkan dengan pengertian solidaritas nasional yang dijelaskan dalam Ensiklopedi Nasional Indonesia, yakni:

Solidaritas nasional, yang disebut juga rasa senasib sepenanggungan, kesetiakawanan dan kebersamaan, pada dasarnya berarti semangant kepeduliaan seseorang, sekelompok orang atau masyarakat, atas nasip orang lain. Semangat inilah yang menumbuhkan sikap-skiap kepahlawanan, kerelaan berkorban, dan kesetiaan untuk ikut merasakan dan membantu kesulitan orang lain. Solidaritas ini pada hakekatnya muncul dari sifat manusia sebagai makluk individu sekaligus makluk sosial. Sebagai makluk sosial, manusia mengakui bahwa dirinya tidak mungkin hidup sendiri, melainkan harus hidup dengan orang lain dengan saling melengkapi dan saling membutuhkan. ${ }^{\mathrm{I}}$

Sedangkan Isasi Diaz menyebutkan:

Solidaritas dimengerti sebagai cara untuk mengekspresikan cinta terhadap sesama pada masa kini. Solidaritas bukanlah sekedar setuju dengan, mendukung, atau yang diinspirasikan oleh persoalan sekelompok orang. Meskipin semuanya bisa menjadi bagian solidaritas, solidaritas sendiri melampaui semua itu. Isasi Diaz mencatat: "Solidaritas harus menggunakan pemahaman kesaling terhubungan yang hadir di antara orang kaya dan miskin atau orang-orang tertindas di antara orang kaya dan miskin atau orang-orang tertindas dan para penindas. Ia menunjuk pada keutuhan yang perlu hadir di atas komunitas-komunitas yang berjuang ${ }^{12}$

\section{METODOLOGI PENELITIAN}

\section{Gambaran Umum Lokasi Penelitian}

\footnotetext{
${ }^{10}$ Depertemen Pendidikan dan Kebudayaan. Kamus Besar Bahasa Indonesia, Edisi Kedua (Jakarta:Balai Pustaka, 1994), s.v. "solidaritas".

${ }^{11}$ Eksiklopedi Nasional Indonesia 15 SF, SY (Jakarta: Cipta Adi Pustaka, 1991), s.v. "Solidaritas Nasional".

${ }^{12}$ Ada Maria Isasi - Diaz, "Solidarity", Susan Brooks Thistlethuaite and May Potter Engel (eds), Live every Voice: Constructing Christian Theologies from the Underside (Maryknoll, New York: Orbis Books, 1998), 31 dikutip Ranto G. Simamora. Misi kemanusiaan dan Globalisasi Teologi Misi dalam konteks globalisasi di Indo-nesia. (Bandung: Ink Media, 2006) 139.
} 
Lokasi penelitian yakni pada Gereja Kemah Injil Indonesia (GKII) yang terletak pada wilayah Administrasi kota Madya Kupang yang meliputi kecamatan Oebobo, kecamatan Pasir Panjang, kecamatan Alak, kecamatan Maulafa dan kecamatan Kota Raja. Ini meliputi 8 gereja yakni, GKII Siloam Oebobo, GKII Sikumana, GKII Efrata Oebufu, GKII Mizpa TDM, GKII Filadelfia Oesapa, GKII Effrata Oebufu Laik, GKII Elshadai Maulafa, GKII Elshadai Air Lobang II, GKII Pos PI Rhema Kota Baru. Ini juga dapat digambarkan dari tabel berikut ini:

\begin{tabular}{|l|l|l|l|}
\hline \multirow{2}{*}{ No } & \multicolumn{2}{|c|}{ Nama Gereja } & \multicolumn{2}{|c|}{ Lokasi } \\
\cline { 3 - 4 } & & \multicolumn{1}{|c|}{ Keluruhan } & \multicolumn{1}{|c|}{ Kecamatan } \\
\hline 1 & GKII Siloam & Oebobo & Oebobo \\
\hline 2. & GKII Ekklesia & Sikumana & Maulafa \\
\hline 3. & $\begin{array}{l}\text { GKII El-Shadai Airlobang } \\
\text { II }\end{array}$ & Sikumana & Maulafa \\
\hline 4. & GKII El-Shadai Maulafa & Mualafa & Maulafa \\
\hline 5 & GKII Effrata-Oebufu & Oebufu & Maulafa \\
\hline 6 & GKII Mizpa & $\begin{array}{l}\text { Tuak } \\
\text { Merah }\end{array}$ & Oebobo \\
\hline 7 & GKII Filadelfia & Oesapa Barat & Pasir Panjang \\
\hline 8 & GKII Pos PI Rhema & Kota Baru & Pasir Panjang \\
\hline 9 & GKII Efata-Oebufu Laik & Maulafa & Maulafa \\
\hline
\end{tabular}

Dalam penelitian ini penulis mengambil fokus penelitian pada GKII yang berada di Kota Madya Kupang yang meliputi 9 jemaat yang ditunjukkan dalam tabel berikut ini:

\begin{tabular}{|c|c|c|c|c|c|}
\hline \multirow[b]{2}{*}{ NO } & \multirow[b]{2}{*}{$\begin{array}{l}\text { Nama } \\
\text { Gereja }\end{array}$} & \multicolumn{2}{|c|}{ Jumlah } & \multirow[b]{2}{*}{$\begin{array}{l}\text { Gembala } \\
\text { Sidang }\end{array}$} & \multirow[b]{2}{*}{$\begin{array}{l}\text { Tahur } \\
\text { Berdir }\end{array}$} \\
\hline & & $\begin{array}{c}\text { Kepala } \\
\text { Keluarga }\end{array}$ & $\begin{array}{c}\text { Jiwa } \\
\text { am }\end{array}$ & & \\
\hline 1. & GKII Siloam & 106 & 415 & $\begin{array}{l}\text { Pdt. Yuliana } \\
\text { Gabriel, S.Th }\end{array}$ & 1955 \\
\hline 2. & GKII Ekklesia & 52 & 343 & $\begin{array}{l}\text { Pdt. Salmon } \\
\text { Atamabi, S.Pd, } \\
\text { MM }\end{array}$ & 1977 \\
\hline 3. & $\begin{array}{l}\text { GKII El-Shadai } \\
\text { Air Lobang II }\end{array}$ & 20 & 102 & $\begin{array}{l}\text { Pdt. Restiti } \\
\text { Nara }\end{array}$ & 2006 \\
\hline 4. & $\begin{array}{l}\text { GKII El-Shadai } \\
\text { Maulafa }\end{array}$ & 20 & 102 & $\begin{array}{l}\text { Pdt. Natanael } \\
\text { Nara Mudji }\end{array}$ & 2006 \\
\hline 5. & $\begin{array}{l}\text { GKII Efata } \\
\text { Oebufu Laik }\end{array}$ & 12 & 74 & Ev. Etni & 1994 \\
\hline
\end{tabular}




\begin{tabular}{|l|l|c|c|l|l|}
\hline & & & & $\begin{array}{l}\text { Eliazer, S.Th, } \\
\text { M.Si }\end{array}$ & \\
\hline 6. & $\begin{array}{l}\text { GKII Efrata } \\
\text { Oebufu }\end{array}$ & 12 & 42 & $\begin{array}{l}\text { Pdt. Yohanis } \\
\text { Pentury, S.Th }\end{array}$ & 1990 \\
\hline 7 & GKII Mizpa & 18 & 78 & $\begin{array}{l}\text { Pdt. Semuel } \\
\text { Laure, S.Th }\end{array}$ & 1997 \\
\hline 8. & GKII Filadelfia & 12 & 50 & $\begin{array}{l}\text { Pdt. Arion } \\
\text { Prata, S.PAK, } \\
\text { M.Pd.K }\end{array}$ & 1998 \\
\hline 9. & $\begin{array}{l}\text { GKII Pos } \\
\text { PI Rhema }\end{array}$ & 6 & 35 & $\begin{array}{l}\text { Ev. Hendrik } \\
\text { Sabandar, } \\
\text { S.Th, MA }\end{array}$ & 2011 \\
\hline
\end{tabular}

Secara organisasi gereja, keberadaan Jemaat GKII yang berada di kota Kupang berada pada wilayah pelayanan GKII Wilayah Indonesia Timur II yang meliputi GKII Daerah Kupang-NTT, GKII Daerah AlorNTT, GKII Daerah Nusa Tenggara Barat (NTB) dan GKII Daerah Bali dan GKII Daerah Sumba yang baru diresmikan pada konfresi wilayah Indonesia Timur II di Alor pada bulan Juli 2011 lalu. Secara khusus untuk GKII Daerah Kupang secara administrasi pemerintahan daerah pelayanan mencakup Kabupaten Rote-Ndao, Kabupaten Sabu Raijua, Kabupaten Kupang, Kotamadya Kupang, Kabupaten Timor Tengah Selan dan Kabupaten Belu. Dengan jumlah keseluruhan jemaat yakni 62 jemaat. Dengan komposisi Kota Madya Kupang 9 Jemaat, Ka-bupaten Rote-Ndao 7 jemaat, Kabuten Sabu Raijua 4 jemaat, Kabupaten Timor Tengah Selatan 23 jemaat, Kabupaten Belu 1 Jemaat dan Kabupaten Kupang 19 Jemaat, dengan gambaran sebagai berikut: ${ }^{14}$

\begin{tabular}{|c|c|c|c|}
\hline No & Lokasi Jemaat & Nama Jemaat & $\begin{array}{l}\text { Jumlah } \\
\text { Jemaat }\end{array}$ \\
\hline 1. & \multirow{8}{*}{$\begin{array}{c}\text { Kota Madya Kupang } \\
9 \text { Jemaat Lokal }\end{array}$} & GKII Siloam Oebobo & \multirow{8}{*}{9 Jemaat } \\
\hline 2. & & GKII EL-Shadai & \\
\hline 3. & & GKII EL-Shadai Air Lobang II & \\
\hline 4 & & GKII Eklesia Sikumana & \\
\hline 5 & & GKII Filadelfia Oesapa & \\
\hline 6 & & GKII Effrata Oebufu & \\
\hline 7 & & GKII Mizpa & \\
\hline 8 & & GKII Pos PI Rhema & \\
\hline
\end{tabular}

${ }^{13}$ Data Sekretariat GKII Daerah Kupang-NTT, 2012.

${ }^{14}$ Data Sekretariat GKII Daerah Kupang 


\begin{tabular}{|c|c|c|c|}
\hline 9. & & GKII Efata Oebufu Laik & \\
\hline 10 & \multirow{7}{*}{$\begin{array}{c}\text { Kabupaten Rote - } \\
\text { Ndao }\end{array}$} & GKII Mongga & \multirow{7}{*}{7 Jemaat } \\
\hline 11 & & GKII Budafuan & \\
\hline 12 & & GKII Nggofa & \\
\hline 13 & & GKII Zion Bokai & \\
\hline 14 & & GKII Pos PI Fegolen & \\
\hline 15 & & GKII Sanama Lidamanu & \\
\hline 16. & & GKII Baa & \\
\hline 17. & \multirow{4}{*}{$\begin{array}{c}\text { Kabupaten Sabu } \\
\text { Raijua }\end{array}$} & GKII Wadumadi & \multirow{4}{*}{4 Jemaat } \\
\hline 18. & & GKII Zion Teriwu & \\
\hline 19. & & GKII Pniel Unujo & \\
\hline 20 & & GKII Calvari Naudue & \\
\hline 21 & \multirow{23}{*}{$\begin{array}{l}\text { Kabupaten Timor } \\
\text { Tengan Selatan (TTS) }\end{array}$} & GKII Oetnana & \multirow{23}{*}{$\begin{array}{c}23 \\
\text { Jemaat }\end{array}$} \\
\hline 22 & & GKII Fautana & \\
\hline 23 & & GKII Tuaome & \\
\hline 24 & & GKII Oenaus & \\
\hline 25 & & GKII Sahan & \\
\hline 26 & & GKII Hakal Dama Maikolen & \\
\hline 27 & & GKII Pos PI Gunung Putih & \\
\hline 28 & & GKII Pos PI Oinoni & \\
\hline 29 & & GKII Siloam Oekamusa & \\
\hline 30 & & GKII Ayalon Nulle & \\
\hline 31 & & GKII Jireh -Soe & \\
\hline 32 & & GKII Alfa Oemega Oenae & \\
\hline 33 & & GKII Boentuka & \\
\hline 34 & & GKII Pilli & \\
\hline 35 & & GKII Sion Hane & \\
\hline 36 & & GKII Talitakumi Oekese & \\
\hline 37 & & GKII Enoana & \\
\hline 38 & & GKII Pos PI Oelfau & \\
\hline 39 & & GKII Nuimanikin & \\
\hline 40 & & GKII Raah Oebaki & \\
\hline 41 & & GKII Doulos Ayoleu & \\
\hline 42 & & $\begin{array}{l}\text { GKII Yehowah Jirreh } \\
\text { Basmuti }\end{array}$ & \\
\hline 43 & & GKII Sammah Tetaf & \\
\hline 44 & \multirow{5}{*}{$\begin{array}{c}\text { Kabupaten Belu } \\
\text { Kabupaten Kupang } \\
\text { Kabupaten Kupang }\end{array}$} & GKII Yehowah Rafa & 1 Jemaat \\
\hline 45 & & GKII Puannasi-Camplong & \multirow{4}{*}{$\begin{array}{c}19 \\
\text { Jemaat }\end{array}$} \\
\hline 46 & & GKII Oelhausus & \\
\hline 47 & & GKII Oelbima & \\
\hline 48 & & GKII Agape Camplong & \\
\hline
\end{tabular}




\begin{tabular}{|c|c|}
\hline 49 & GKII Nefopal \\
\hline 50 & GKII Pua'na \\
\hline 51 & GKII Oelhaususu \\
\hline 52 & GKII Pos PI Oebola \\
\hline 53 & GKII Imanuel Oepleo \\
\hline 54 & GKII Kolbate \\
\hline 55 & GKII Butin \\
\hline 56 & GKII Sesawi Oehaen \\
\hline 57 & GKII Fatualimat \\
\hline 58 & GKII Neufmuti \\
\hline 59 & GKII Imanuel Oepleo \\
\hline 60 & GKII Oelbima \\
\hline 61 & GKII Bukit Zion Butin \\
\hline 62 & GKII Pos PI Marturia Oenesu \\
\hline 63 & GKII Efata Kanikanutu \\
\hline
\end{tabular}

Keberadaan gereja-gereja yang berada di wilayah kabupaten Rote-Ndao, kabupaten Sabu-Raijua, kabupaten Kupang, kabupaten Timor Tengah Selatan dan Belu pengembangan pelayanannya berbasis di kota Kupang sebagai titik awal pelayanan Gereja Kemah Injil Indonesia Daerah Kupang - NTT.

\section{Prosedur Penelitian}

Tahap Persiapan

Peneliti dalam tahap ini mencari informasi berhubungan erat dengan masalah-masalah sosial baik secara internasional, nasional, daerah dan lokal yang menunjukkan suatu kondisi masyarakat saat ini yang tidak terlepas dari masalah kemiskinan, kesehatan, pendidikan, keseyahteraan sosial dan berbagai kondisi sulit yang meliputi bidang ekonomi, sosial, hukum dan politik. Dan juga mempelajari kebenaran firman Allah yang berhubungan dengan realita kondisi tersebut. Sehingga menimbulkan suatu pertanyaan yang bersifat aplikasi, yakni dalam kondisi ini apa yang dapat dilaksanakan oleh gereja sebagai bagian dari tugas perutusannya ke dalam dunia sebagai garam dan terang bagi dunia ini.

\section{Tahap Penelitian}

Tahapan penelitian yang dilakukan penulis diawali sejak persetujuan judul penulisan karya ilmiah kepada pembimbing. Dilakukan penelitian awal untuk pembuatan proposal penelitian untuk diuji. Pada tahap selanjutnya melakukan penelitian lanjutan untuk mengetahui sejauh mana aplikasi dari konsep ajaran solidaritas Kristen 
pada jemaat GKII Kota Kupang. Berdasarkan hasil analisa angket, wawancara, maupun data-data dukumen yang diperoleh penulis akan selama melakukan penelitian. Pada akhirnya penulis memberikan kesimpulan dan saran berhubungan dengan hasil analisa data yang telah diperoleh dari lokasi penelitian yakni jemaat GKII Kota Kupang.

\section{Teknik Pengumpulan Data}

Penulis memperoleh data melalui penelitian kepustakaan, dan penelitian lapangan. Dalam penelitian lapangan data diperoleh melalui teknik observasi langsung, wawancara, questioner dan data dari dokumen-dokumen gereja yang diperoleh selama kegiatan penelitian.

Observasi langsung, peneliti melihat secara langsung aplikasi pelaksanaan soli-daritas Kristen dalam jemaat yang ada di kota Kupang. Teknik Wawancara, peneliti akan mewawancarai beberapa gembala untuk memperoleh gambaran mengenai aplikasi ajaran solidaritas Kristen dalam jemaat. Teknik pengumpulan data melalui questioner, peneliti membuat daftar pertanyaan yang berhubungan dengan penelitian dan diberikan untuk diisi oleh gembala sidang, majelis dan tua-tua jemaat ini pun dapat berkisar antara 35-69 orang yang disesuaikan pula dengan jumlah jemaat setiap gereja. Data dokumen gereja, peneliti akan peroleh berhubungan erat dengan hasil-hasil keputusan Rapat Umum Jemaat yang berhubungan erat dengan aplikasi solidaritas Kristen dan informasi lainnya yang tertulis berhubungan erat dengan kegiatan jemaat yang berhubungan erat dengan aplikasi solidaritas Kristen yang dilaksanakan oleh jemaat.

\section{Tahap Pelaksanaan}

\section{Jenis Penelitian}

Jenis penelitian yang dipakai dalam penelitian yakni deskriptif kuantitatif. Penelitian deskriptif, menurut Sumadi Suryabrata, yakni:

Secara harafiah, penelitian deskriptif adalah penelitian yang bermaksud untuk mem-buat pencandraan (deskripsi) mengenai situasi-situasi atau kejadian-kejadian. Dalam arti ini penelitian deskriptif itu adalah akumulasi data dasar dalam cara deskriptif semata-semata tidak perlu mencari atau menerangkan saling hubungan, mestest hipokarya ilmiah, membuat ramalan, atau mendapatkan makna dan implikasi, walaupun pene-litian yang bertujuan untuk menemukan hal-hal tersebu dapat mencakup juga metode-metode deskriptif. ${ }^{15}$

\footnotetext{
${ }^{15}$ Sumadi Suryabrata. Metodologi Penelitian, Cetakan keenam (Jakarta: Rajawali Pers, 1991), 20-21.
} 
Lebih lanjut dijelaskan,

Penelitian deskriptif (Descriptive Research) Penelitian deskriptif berkaitan dengan pengumpulan data untuk memberikan gambaran atau penegasan suatu konsep atau gejala, juga menjawab pertanyaan-pertanyaan sehubungan dengas status subyek penelitian pada saat ini. Data deskriptif pada umumnya dikumpulkan melalui suatu survey angket, wawancara, atau observasi. Karena peneliti pada umumnya membuat pertanyaanpertanyaan untuk keperluaan yang tertentu, maka instrumentinstrumen harus dibuat setiap penyelidikan, sesuai dengan hipokarya ilmiahnya. ${ }^{16}$

\section{Teknik Analisa Data}

Teknik menganalisis data merupakan suatu langkah yang sangat kritis dalam penelitian. ${ }^{17}$ Pada bagian ini peneliti menggunakan metode deskriptif, yakni menganalisis menurut isinya ${ }^{18}$. Peneliti menganalisa data dan menguraikanya secara deskriptif. Secara kuantitatif karena berhubungan dengan data analisa terhadap angket yang diberikan. Dari hasil analisa ini penulis mengambil kesimpulan dan saran-saran bagi aplikasi pelaksanaan ajaran solidaritas Kristen pada GKII Kota Kupang.

Analisa data untuk angket dalam riset ini menggunakan skala Guttman dengan pengukuruan sebagai berikut:

Variabel $\mathrm{P}=\underline{\mathrm{R}} \times 100 \%=\ldots \ldots . . \%$

A

$\mathrm{P}=$ Presentase masing - masing variabel

$\mathrm{R}=$ Jumlah responden

$\mathrm{A}=$ Jumlah Angket

\section{ANALISIS HASIL PENELITIAN DAN PEMBAHASAN}

Analisa hasil penelitian dikaji dalam bentuk aplikasi teologi Solidaritas Kristen yang nyata dalam wujud solidaritas Kristen yakni solidaritas Trasformatif, solidaritas Misiologis, solidaritias Inkarnatif dan solidaritas holistik.

\footnotetext{
${ }^{16}$ Depertemen Agama R.I. Direktorat Jenderal Bimbingan Masyarakat (Kristen) Protestan Proyek Peningkatan Pendidikan Agama Kristen DI Perguruan Tinggi. Penerapan Metode Kuantitatif Dalam Penelitian Gerejawi. (Jakarta: Dirjen Bimas Kristen, 1997), 8-9.

${ }^{17}$ Suryabrata, Metodologi Penelitian(Jakarta: Rajawali Pers, 1991) , 94.

${ }^{18}$ Ibid.
} 


\section{Solidaritas Trasformatif}

Pelaksanaan solidaritas trasformatif, diwujudkan dalam bentuk pendidikan, diakonia trasformatif dan peran suara kenabian gereja. Untuk mengetahui sejauh mana aplikasi dalam GKII Kota Kupang ada tujuh pertanyaan yang diberikan yakni dari pertanyaan nomor 1 - 7 . Penulis mencoba menganalisa setiap pertanyaan dan memberi kesimpulan dari jawaban yang diberikan. Pertanyaan itu adalah:

Pertama, Menurut pemahaman saudara, apakah melayani orang yang miskin, teraniaya, yang susah, orang yang sakit, kaum yang lemah, orang yang terhilang adalah bagian dari tanggung jawab misi gereja? Dari jawaban angket ini menunjukkan adanya pemahaman yang sama oleh semua gereja Kemah Injil Kota Kupang mengenai tanggungjawab pelayanan bagi orang yang miskin, teraniaya, yang susah, orang yang sakit, kaum yang lemah, orang yang terhilang adalah bagian dari tanggung jawab misi gereja.

Kedua, Dalam Pengamatan saudara apakah Gereja Kemah Injil Indonesia yang ada di kota Kupang sudah melaksanakan pelayanan bagi mereka (sperti pertanyaan nomor 1)? Dari penjelasan angket menunjukkan secara umum gereja-gereja Kemah Injil yang ada di kota Kupang telah melaksanakan pelayanan, namun masih ada keraguan yang datang dari gereja-gereja Kemah Injil yang lain, yang masih melihat bahwa pelayanan ini belum dilaksanakan secara maksimal. Ini dibuktikan dengan ada 33 orang dari 55 orang responden menyawab "ya" yakni 58,92\%. Bahkan ada 5 orang dari 55 responden menjawab "tidak" 8,92\% dan 17 orang dari 56 orang responden yang menjawab "ragu-ragu" yakni 30,35 \%.

Ketiga, Apakah gereja melaksanakan program pelayanan di bidang pendidikan umum? Dari hasil penjelasan angket menunjukkan bahwa gereja-gereja Kemah Injil yang ada di kota Kupang menyadari pelayanan pendidikan umum adalah bagian dari pelayanan gereja. Namun dalam kenyataan hanya satu gereja Kemah Injil di Kota Kupang yang mempunyai sekolah umum yakni Ekklesia Sikumana. Salmon Atamabi menjelaskan, "Taman Kanak-kanak Cemara yang telah berdiri sejak tahun 2004 (angkatan yang ke-8) dan telah menamatkan 283 anak. Sedangkan jumlah siswa tahun pelajaran 2012/2013 sebanyak 29 orang." ${ }^{19}$ Sedangkan gereja yang lain belum mempunyai pendidikan secara formal. GKII Siloam Oebobo telah menjadi keputusan Rapat Umum Jemaat sejak tahun 2009 namun belum dapat dilaksanakan hingga saat ini. Secara keseluruhan dari 56 responden menjawab "ya", 23 responden dari 56 orang responden atau 41,07\%. Ada 24 responden yang menjawab

${ }^{19}$ Salmon Atamabi, Wawancara Oleh Penulis, Kupang, Nusa Tenggara Timur, 19 Juli 2012. 
Gereja Kemah Injil Kota Kupang tidak mempunyai Sekolah Umum yakni 24 responden atau 42,85\%. Sedangkan, yang menjawab "raguragu" yakni 9 orang responden dari 56 orang responden atau 16,07\% .

Keempat, Apakah Gereja melaksanakan program pelatihan kewirausahaan bagi jemaat? Dari penjelasan angket ini menunjukkan umumnya gereja-gereja Kemah Injil di Kota Kupang umumnnya tidak mempunyai program pelatihan kewirausahaan bagi jemaat. Ini terbukti dari 56 orang responden 37 orang yang menjawab gereja tidak mempunyai program tersebut, yakni 66,07 \% . Sedangkan yang menyebut "ya", 11 orang responden dari 56 orang responden, yakni 19,64 $\%$. Sedangkan yang "ragu-ragu" ada 8 orang responden dari 56 orang responden yakni 14, 28\% .

Kelima, Apakah gereja mempunyai anggota jemaat yang dapat memperlengkapi jemaat yang lain dalam pendidikan keterampilanketerampilan bagi kemandirian hidup? Dari penjelasan ini menunjukkan bahwa dalam jemaat GKII Kota Kupang ada anggota jemaat yang mempunyai kemampuan khusus yang dapat melengkapi jemaat melalui kegiatan kewirausahaan. Ini dapat dilihat dari 35 orang responden dari 56 orang responden yang menjawab "ya", bahwa gereja mempunyai anggota jemaat yang memperlengkapi jemaat yang lain melalui pelatihan kewirausahaan, yakni $62,5 \%$. Sedangkan yang menjawab tidak 13 orang responden dari 56 orang responden yakni $23,21 \%$ dan yang menjawab "ragu-ragu" ada 8 orang responden dari 56 orang responden yakni 14,28 $\%$.

Keenam, Apakah gereja melaksanakan program pengembangan ekonomi umat? Dari analisa angket menunjukkan Gereja Kemah Injil Indonesia di Kota Kupang belum semua melaksanakan program pengembangan ekonomi bagi umat. Dari data menunjukkan dari 56 responden masing-masing 25 responden menjawab ya dan tidak yakni $44,64 \%$ sedangkan ragu-ragu 6 responden dari 56 orang responden yakni 10,71\%. Salmon Atamabi, menyebutkan mengenai salah satu cara pengembangan ekonomi umat yakni melalui koperasi. "Koperasi kita sudah 2 tahun 6 bulan berjalan. Jumlah anggota sudah 30 orang, dengan jumlah simpanan sudah mencapai 30 juta". ${ }^{20}$ Sedangkan jemaat Filadelfia Oesapa dari 5 responden ada 4 responden yang menyebutkan gereja melaksanakan program pengembangan ekonomi umat yakni $80 \%$. Hasil data yang diperoleh dari angket yang diberikan, kegiatan yang dilaksanakan sebagai bagian dari program pengembangan ekonomi umat yakni berupa membentuk kelompok usaha kaum perempuan berupa kripik pisang dan ubi. Untuk jemaat Siloam Oebobo dari 16 responde

\footnotetext{
${ }^{20}$ Salmon Atamabi, Wawancara Oleh Penulis, Kupang, Nusa Tenggara Timur, 18 Juli 2012
} 
ada 8 responde yang menjawab ada program pengembangan ekonomi umat yakni 50\%. Berdasarkan pengamatan penulis selama 3 tahun telah berjalang. Bapak Daniel Kaleraga ketua usaha simpan pinjam jemaat yang bernama Kemah Sejahtera menjelaskan, "Usaha ini berdiri sejak 10 April 2009 lalu dengan jumlah simpanan Rp. 26. 433. 000 ditambah pinjaman modal dari gereja Rp. 10.000.000, sehingga total simpanan Rp. 36.433.000 dengan anggota berjumlah 42 orang. Dari jumlah ini, anggota yang telah meminjam uang sebanyak 38 orang." ${ }^{21}$

Ketujuh, Apakah geraja juga mempunyai tanggungjawab melaksanakan peran secara aktif melalui peran suara kenabian gereja kepada pemerintah mengenai berbagai praktek penyimpangan hukum, dan sosial di dalam masyarakat saat ini? Dari analisa angket menunjukkan bahwa dari 56 responden tidak semua menjawab "ya", bahwa gereja juga mempunyai tanggung jawab melaksanakan peran secara aktif melalui peran suara kenabian gereja kepada pemerintah mengenai berbagai praktek penyimpangan hukum, dan sosial di dalam masyarakat saat ini. Dari 56 respon, ada 30 responden yang menjawab "ya", yakni 53,57\%. Yang menjawab "tidak", ada 17 responden atau $30,35 \%$, sedangkan yang menjawab "ragu-ragu", ada 9 orang responden atau $16,07 \%$. Berdasarkan pengamatan penulis selama kuran waktu 10 tahun terakhir ini dari jemaat Gereja Kemah Injil yang ada di kota Kupang baru 2 orang yang duduk dalam legislatif. Satu di Kabupaten Kupang dan satu di Kota Kupang. Sedangkan surat rekomendasi yang diberikan gereja-gereja lokal kepada pemerintah sebagai bagian dari suara kenabian gereja terhadap kenyataan penyimpangan sosial yang terjadi dalam masyarakat. Dalam pengamatan penulis dalam kurun waktu 10 tahun terakhir ini tidak ada.

Sebagai kesimpulan aplikasi dari ajaran solidaritas Kristen bagi GKII Jemaat Kota Kupang secara khusus solidaritas trasformatif, dari jawaban angket nomor 1 menunjukkan adanya pemahaman yang sama oleh semua Gereja Kemah Injil Kota Kupang mengenai tanggungjawab pelayanan bagi orang yang miskin, teraniaya, yang susah, orang yang sakit, kaum yang lemah, orang yang terhilang adalah bagian dari tanggung jawab misi gereja. Namun dalam pelaksanaan untuk menolong masyarakat dan jemaat yang miskin, teraniaya, susah, yang sakit dan lemah serta terhilang belum dilaksanakan secara maksimal. Dibuktikan dengan ada 33 orang dari 55 orang responden menyawab ya yakni $58,92 \%$. Bahkan ada 5 orang dari 55 responden menjawab tidak 8,92\% dan 17 orang dari 56 orang responden yang menjawab ragu-ragu yakni $30,35 \%$. Untuk pelayanan di bidang pendidikan umum hanya baru 19 Juli 2012.

${ }^{21}$ Daniel Kaleraga, Wawancara Oleh Penulis, Kupang, Nusa Tenggara Timur tanggal 
dilaksanakan oleh jemaat Ekklesia Sikumana, gereja yang lainnya dalam tahap perencanaan untuk dilaksanakan dalam 1 hingga 2 tahun ke depan. Untuk pelaksanaan diakonia trasformatif yang berupa pelatihan kewirausahaan belum dilaksanakan secara maksimal oleh semua GKII di Kota Kupang walaupun ada jemaat yang mempunyai ketrampilan khusus untuk melaksanakannya namun belum diberdayakan untuk melaksanakan program tersebut dengan baik. Salah satu jemaat yakni Filadelfia Oesapa sudah melaksanakan pelatihan kewirausahaan dalam bentuk pelatihan keripik pisang dan ubi bagi unit usaha kaum perempuan.

Namun dari sisi yang lain ada dua gereja yakni GKII Siloam dan GKII Ekklesia yang telah melaksanakan diakonia trasformatif berupa koperasi atau unit usaha keuangan dalam gereja yang dapat menolong jemaat memberdayakan potensi yang ada.

Secara khusus dalam peran suara kenabian gereja, belum dilaksanakan secara maksimal. Gereja belum memberikan masukan secara kontruktif melalui kritik dan saran secara tertulis kepada pemerintah dan DPR mengenai kondisi sosial yang tidak benar di dalam masyarakat kota Kupang.

\section{Solidaritas Misiologis}

Aplikasi ajaran solidaritas Kristud dalam wujud solidaritas misiologis di nyatakan dalam pelayanan penginjilan dan pelayanan bagi anak-anak yang tidak mampu di dalam gereja dan masyarakat. Untuk mengetahui sejauh mana aplikasi dalam GKII Kota Kupang ada 3 pertanyaan yang diberikan. Penulis mencoba menganalisa setiap pertanyaan dan memberi kesimpulan dari jawaban yang diberikan.

Pertama, Apakah gereja mempunyai program penginjilan yang terprogram secara baik untuk menjangkau orang-orang yang belum percaya kepada Kristus di kota Kupang? Dari penjelasan angket menunjukkan bahwa gereja-gereja Kemah Injil Kota Kupang belum secara maksimal mempunyai program untuk menjangkau orang-orang yang belum percaya yang berada di kota Kupang. Data menunjukkan dari 56 responden ada 31 responden yang menjawab "ya" atau 55, 35\%. Dan 10 responden menjawab "tidak" atau $17,85 \%$. Sedangkan yang "raguragu" ada 15 responden atau 26,78\%. Penulis mengamati selama ini memang gereja-gereja lokal mempunyai program penginjilan namun masih terbatas kepada penginjilan di antara orang-orang di dalam gereja dan pembukaan pos-pos pelayanan baru yang umumnya ada jemaatjemaat yang jarak tinggalnya jauh dari gereja pusat. Namun khusus untuk menjangkau para pendatang yang belum percaya pada Kristus dari suku Bugis, Makassar, Jawa dan Sumatra pelaksanaannya belum terprogramkan dengan baik. 
Kedua, Apakah gereja mempunyai persembahan khusus yang dilaksanakan setiap minggu/bulan/tahun untuk penginjilan dan pelayanan diakonia yang dilaksanakan gereja untuk mendukung program penginjilan dan pelayanan diakonia dalam gereja dan kepada masyarakat? Dari penjelasan angket menunjukkan bahwa gereja-gereja Kemah Injil Kota Kupang telah mempunyai persembahan khusus yang dilaksanakan setiap minggu/ bulan/ tahun untuk penginjilan dan pelayanan diakonia yang dilaksanakan gereja untuk mendukung program penginjilan dan pelayanan diakonia dalam gereja dan kepada masyarakat. Secara keseluruhan dari 56 responden ada 50 responden yang menjawab "ya", atau 89,28\%. Sedangkan yang menjawab "tidak" ada 4 responden atau 7,14\% dan yang menjawab "ragu-ragu" ada 2 responden atau 3,57\%. Salmon Atamabi, gembala sidang GKII Ekklesia Sikumana, menjelaskan, "kami mempunyai persembahan khusus setiap bulan untuk penginjilan dan pendidikan dan rencana dalam bulan Oktober akan pembukaan satu pos baru di Alak.."22 Untuk GKII Siloam Oebobo berdasarkan data laporan bendahara pada Rapat Umum Jemaat Jemaat Minggu 15 Juli 2012, untuk pendidikan dana sejak tanggal 1 Agustus 2009-30 Juni 2012 berjumlah Rp. 40. 815. 450. Sedangkan untuk Penginjilan dana yang diberikan jemaat berjumlah Rp. 60. 533. 650. ${ }^{23}$ Dana penginjilan ini diberikan untuk membantu hamba-hamba Tuhan yang berada di pedesaan dan pelayanan penginjilan kepada jemaatjemaat yang berada di pedesaan.

Ketiga, Apakah gereja mempunyai program untuk menolong anakanak yang kurang mampu? Pada umumnya jemaat-jemaat GKII Kota Kupang mempunyai program untuk menolong anak-anak yang kurang mampu. Ini dibuktikan melalui tanggapan 56 responden ada 37 responden yang menjawab "ya" atau 66,07\%. Sedangkan tidak ada 13 responden atau $23,21 \%$ dan yang menjawab "ragu-ragu" ada $10,71 \%$. Berdasarkan pengamatan penulis ada dua gereja yakni GKII Ekklesia Sikumana dan GKII Siloam Oebobo yang melakukan kemitraan dengan Lembaga Compassion International untuk menolong anak-anak yang kurang mampu dalam gereja maupun di lingkungan sekitar gereja. GKII Siloam Oebobo saat ini mempunyai Pusat Pengembangan Anak (PPA) IO-628 Siloam yang dimulai sejak tahun 2009 dan saat ini jumlah 193 anak yang mengikuti kegiatan pembinaan pada Pusat Pengembangan Anak dalam bidang spiritual, intelektual, kesehatan dan sosial-emosional. ${ }^{24}$ Lebih Juli 2012.

${ }^{22}$ Salmon Atamabi, Wawancara Oleh Penulis, Kupang, Nusa Tenggara Timur, 18

${ }^{23}$ Hasil rekapan Rapat Umum Jemaat Gereja Kemah Injili Indonesia Jemaat Siloam Kupang, Minggu 15 Juli 2012.

${ }^{24}$ Data Pusat Pengembangan Anak IO-628 GKII Siloam Oebobo. 
lanjut mengenai pelayanan bagi anak yang kurang mampu selama kurang lebih 13 tahun sejak almarhum Pdt. Soleman Penjaha, S.Th meninggal dunia. GKII Siloam dalam Rapat Umum Jemaat telah mengambil keputusan untuk membiayai pendidikan 3 orang almarhum hingga saat ini. Berdasarkan laporan bendahara pada Rapat Umum Jemaat GKII Siloam Oebobo Minggu, 15 Juli 2012 data menunjukkan sejak periode Agustus 2009 - Juni 2012 bantuan dana yang telah dikumpulkan jemaat Rp. 15.232.511,72 (Lima belas juta dua ratus tiga puluh dua ribu lima ratus sebelas rupiah, tujuh puluh dua sen). Dana yang telah terpakai untuk biaya pendidikan dalam periode tersebut Rp. 6.647.280, 56. (Enam juta enam ratus empat puluh tujuh dua ratus delapan puluh rupiah, lima puluh enam sen). Saldo tertanggal 14 Juli 2012 sebesar Rp. 6.647.280,56 (Enam juta enam ratus empat puluh tujuh dua ratus delapan puluh, lima puluh enam sen). ${ }^{25}$

GKII Ekklesia Sikumana, menurut Yane Kamau, Kordinator Pusat Pengembangan Anak Agape (PPA IO-41 Agape), menjelaskan, "PPA IO 4l Agape telah berdiri sejak tanggal 15 Agustus 1979 dan jumlah anak yang dilayani sekarang berjumlah 256 orang anak. ${ }^{26}$ Sebagai kesimpulan dari aplikasi pelaksanaan ajaran solidaritas Kristen dalam wujud solidaritas misiologis dalam bidang penginjilan telah dilaksanakan namun masih pada penginjilan di dalam gereja, belum menjangkau orang-orang yang berasal dari luar etnis Nusa Tenggara Timur yang berada di Kota Kupang. Memang sudah ada persembahan yang diberikan namun persembahan belum difokuskan untuk dipakai menjangkau orang-orang tersebut. Sedangkan pelayaan bagi anak-anak yang kurang mampu baik dalam gereja maupun masyarakat belum semua jemaat melakukannya secara maksimal. Kecuali 2 jemaat yakni GKII Siloam dan GKII Eklesia yang sudah melakukannya dengan melakukan kemitraan dengan Yayasan Compassion International.

\section{Solidaritas Inkarnatif}

Aplikasi ajaran solidaritas Kristud dalam wujud solidaritas Inkarnatif yang dinyatakan dalam pelayanan gereja bagi orang miskin dan pelayanan doa syafaat gereja. Untuk mengetahui sejauh mana aplikasi dalam GKII Kota Kupang ada 2 pertanyaan yang diberikan. Penulis mencoba menganalisa setiap pertanyaan dan memberi kesimpulan dari jawaban yang diberikan.

\footnotetext{
${ }^{25}$ Laporan Keuangan Anak-anak Alm. Pdt. Soleman Penjaha, S.Th, periode Agustus 2009 - Juni 2012, pada Rapat Umum Jemaat GKII Siloam Oebobo, Minggu 15 Juli 2012.

${ }^{26}$ Yane Kameng, Wawancara Oleh Penulis, Kupang, Nusa Tenggara Timur, 18 Juli 2012.
} 
Pertama, Apakah gereja selama ini mempunyai program pelayanan doa bagi suku-suku terabaikan secara tetap? Berdasarkan tanggapan dari 56 responden menunjukkan bahwa GKII Kota Kupang secara umum telah mempunyai program secara tetap untuk mendoakan suku-suku terabaikan yakni ada 43 responden yang menjawab ya atau $76,78 \%$. Sedangkan yag menjawab tidak ada 10 responden atau $17,85 \%$ dan raguragu sebanyak 3 responden atau 5,35\%. Bila dilihat berdasarkan jemaat, hanya ada 3 jemaat yang menjawab ya atau 100\% bahwa mempunyai program secara rutin yakni GKII jemaat Siloam Oebobo, Filadelfia Oesapa dan Mizpa TDM. Berdasarkan angket yang diberikan jemaat Mizpa, Filadelfia maupun GKII Siloam mempunyai kelompokkelompok doa yang melakukan kegiatan setiap hari Rabu Sore.

Kedua, Apakah gereja mempunyai kelompok-kelompok doa tetap yang selalu bertemu dalam program doa syafaat bagi bangsabangsa/penginjilan/suku-suku terabaikan. Dari hasil tanggapan responden menunjukkan bahwa GKII jemaat Kota Kupang secara umum mempunyai kelompok kelompok-kelompok doa tetap yang selalu bertemu dalam program doa syafaat bagi bangsabangsa/penginjilan/suku-suku terabaikan ini berdasarkan jawaban dari 43 responden dari 56 responden atau 76,78\% yang menjawab "ya". Ada 7 responden atau 12,5\% yang menjawab "tidak" dan ada 6 responden yang menjawab "ragu-ragu" atau $10,71 \%$. Secara khusus penulis mengamati di Jemaat GKII Siloam Oebobo ada 12 kelompok doa yang dibentuk untuk berdoa setiap hari Rabu, namun hingga kini ada 3 kelompok yang masih berjalan untuk terlibat dalam pelayanan doa syafaat gereja. Selain ada kegiatan doa puasa rutin yang dilaksanakan setiap hari Sabtu dari pukul 10 pagi hingga pukul 15.00. Pada umumnya kegiatan doa dilaksanakan pada hari Rabu. Bagi jemaat Ekklesia Sikumana berdasarkan pengamatan penulis ada kelompok doa Ayalon yang bertemu secara rutin pada setiap hari Senin jam 6 sore yang mendoakan penginjilan dan pelayanan bagi suku-suku terabaikan.

Dari jawaban atas dua pertanyaan tersebut tidak dapat disangkal berdasarkan data dan pengamatan penulis belum semua jemaat termobilisasi secara baik dalam pelayanan ini. Namun sudah ada tanda menuju perubahan yakni dalam pengamatan penulis ada beberapa gereja yang telah memilih majelis khusus untuk menanggani pelayanan doa dalam gereja yakni seksi doa (GKII Siloam Oebobo, Ekklesia Sikumana dan Mizpa TDM) dan pada aras Badan Pengurus Daerah telah dibentuk komisi doa untuk dapat memobilisasi gereja-gereja lokal dalam pelayanan doa. Bahan-bahan doa untuk pelaksanaan pelayanan ini dari pengamatan penulis telah ada upaya dengan memperolehnya dari Jaringan Doa Nasional dan berita-berita dari media cetak dan elektronik. 


\section{Solidaritas Holistik}

Aplikasi ajaran solidaritas Kristud dalam wujud solidaritas holistik dinyatakan dalam pelayanan gereja secara utuh. Untuk mengetahui sejauh mana aplikasi dalam GKII Kota Kupang ada 2 pertanyaan yang diberikan. Penulis mencoba menganalisa setiap pertanyaan dan memberi kesimpulan dari jawaban yang diberikan.

Pertama, Apakah gereja memberi kesempatan yang luas bagi semua anggota jemaat untuk terlibat dalam pelayanan gereja? Dari hasil jawaban 56 responden menunjukkan bahwa pada umumnya GKII Kota Kupang memberi kesempatan seluas-luasnya kepada semua jemaat untuk terlibat dalam pelayanan gereja. Ada 52 responden menjawab "ya", atau $92,85 \%$. Sedangkan "tidak" hanya 1 respon atau $1,78 \%$ dan "raguragu" 3 responden atau 5,35\%.

Kedua, Sejauh pemahaman saudara apakah program gereja saat ini telah men-yentuh kebutuhan umat dan masyarakat secara utuh (baik jasmani dan rohani)? Dari tanggapan 56 responden menunjukkan bahwa program-program Gereja Kemah Injil Kota Kupang belum sepenuhnya memenuhi kebutuhan umat dan masyarakat secara utuh (secara jasmani dan rohani). Sebab dari 56 responden ada 21 responden yang menjawab sudah memenuhi atau 37,5\%. 11 responden menjawab "tidak", atau 19,64\% sedangkan 24 responden menjawab "ragu-ragu" atau 42,83\%. Dari kedua pertanyaan tersebut dapat disimpulkan bahwa aplikasi pelaksanaan solidaritas holistik dalam GKII Kota Kupang mempunyai peluang besar untuk diting-katkan karena dari pihak gereja memberi kesempatan kepada semua jemaat untuk ter-libat dalam segala bidang pelayanan. Sehingga dalam setiap pertemuan Rapat Umum Jemaat dan Rapat Kerja Jemaat perlu dipikirkan secara baik untuk memutuskan bentuk-bentuk pelayanan gereja yang menjawab kebutuhan umat dan masyarakat secara utuh.

\section{PENUTUP}

\section{Kesimpulan}

Berdasarkan pembahasan yang dijelaskan oleh penulis, maka dapat disimpulkan, yakni:

Pertama, gereja di Indonesia pada umumnya dan secara khusus GKII kota Kupang dengan melihat berbagai kenyataan masalah sosial di dalam masyarakat yakni kemiskinan, ketidakadilan, berbagai penyakit menular yang dirangkumkan dalam permasalahan bersama dalam Millinium Development Goal berbagai masalah sosial lainnya baik itu korupsi, kolusi, nepotisme, monopoli, keadilan dalam hukum dan HAM menunjukkan bahwa gereja Indonesia dan secara khusus GKII Kota 
Kupang sudah saatnya untuk menyatakan solidaritasnya yang nyata dalam kata dan perbuatan.

Kedua, dalam pelaksanaan solidaritasnya, gereja harus melaksanakan dalam konsepsi alkitabiah yang benar, yakni: didasarkan atas sifat Allah sendiri, yang adalah kasih dan berlas kasihan terhadap penderitaan umat manusia. Dan berpusat pada inkarnasi Allah di dalam sejarah umat manusia di dalam pribadi Kristus serta bertujuan memenuhi kebutuhan manusia secara utuh, baik jasmani dan rohani.

Ketiga, dalam pelaksanaan solidaritasnya, gereja perlu melihat kepada wujud solidaritasnya, gereja perlu melihat kepada wujud solidaritas Kristen yang telah diberikan oleh Kristus, jemaat mula-mula dan rasul Paulus. Wujud solidaritas Kristus dalam pelayanan dinyatakan kepada orang yang terhilang dalam semua lapisan sosial dan membawanya kembali dalam persekutuan dengan Allah. Kepada orang yang miskin, Ia memberitakan kabar bahagia, menyambut dan mengidentifikasikan diri-Nya dengan mereka (Matius 25:31-36).

Keempat, dalam merefleksikan konsep solidaritas Kristen bagi pelayanan masa kini dalam konteks Indonesia secara umum dan GKII Kota Kupang secara khusus dapat dilaksanakan dalam bentuk solidaritas trasformatif, misiologis, inkarnatif dan solidaritas holistik. Keempat bentuk solidaritas ini, saling berhubungan erat. Solidaritas trasformatif, dapat dilaksanakan melalui program pendidikan, diakonia trasformatif dan peran suara kenabian gereja. Melalui pendidikan di dalam jemaat, bertujuan memberntuk ethos kerja dan kedasaran sosial mengenai tanggung jawab untuk terlibat dalam berbagai masalah sosial di dalam masyarakat. Diakonia trasformatif, dilaksanakan melalui program motivator pembangunan, untuk membentuk dan mendorong masyarakat dalam pem-bangunan dengan bekerjasama dengan instansiinstansi pemerintah yang terkait. Solidaritas misiologis, dapat dilaksanakan melalui penginjilan dan pelayanan kasih. Sedangkan solidaritas holistik, yang dapat dilaksanakan oleh gereja di Indonesia dan lebih khusus GKII Kota Kupang , yakni melalui pelayanan multi dimensi. Yakni, terlibat seluruh anggota jemaat dalam berbagai disiplin ilmu melalui suatu pelayanan yang terpadu di dalam jemaat untuk dapat ditingkatkan melalui suatu pengkajian yang melibatkan semua komponen dalam jemaat untuk menyusun suatu rencana pelayanan strategis gereja untuk 10-20 tahun mendatang.

Kelima, Gereja dengan pemahaman yang benar akan konsep teologis solidaritas Kristen dan melaksanakannya dalam tindakan solidaritas yang nyata, memberikan kesaksian yang kuat mengenai Kristus dan menjadikan agama Kristen, sebagai agama yang dapat diterima dan membumi dalam negara Indonesia dan lebih khusus di kota 
Kupang yang mayoritas penduduknya beragama Kristen dapat sebagai cermin dari kasih Kristus bagi daerah-daerah lain di Indonesia.

\section{KEPUSTAKAAN}

\section{Alkitab}

Alkitab. Bahasa Indonesia Terjemahan Baru. Jakarta: Lembaga Alkitab Indonesia, 2002.

\section{Ensiklopedi Dan Kamus}

Depertemen Pendidikan dan Kebudayaan. Kamus Besar Bahasa Indonesia Edisi Kedua, Jakarta: Balai Pustaka, 1994.

Ensiklopedia Alkiab Masa Kini Jilid I: A-L. Jakarta:Yayasan Komunikasi Bina Kasih/OMF, 1995.

\section{Buku-buku}

Abineno , J. L. Ch., Gereja Dan Ibadah Gereja . Jakarta: BPK. Gunung Mulia, 1986. ,Pokok-Pokok Penting Dari Iman Kristen Cetakan kedua, Jakarta: BPK. Gunung Mulia, Artanto, Widi . Menjadi Gereja Misioner Dalam Konteks Indonesia Yogyakarta:Kanisius Dan BPK. Gunung Mulia, 1997.

Bagster, Samuel, , The Analytical Greek Lexicon. New York: Samuel Bagster and Son Limited 80 Wigmore Street London.

Bauckham, Richard. Teologi Mesianis Menuju Teologi Mesianis Menurut Jurgen Moltman . Jakarta: BPK. Gunung Mulia, 1993.

Berkhof, Louis. Teologi Sistematika Volume I Doktrin Tentang Allah Jakarta: Lembaga Reformed Injili Indonesia, 1993.

Bolkestein, M. H., Kerajaan Yang Terselubung . Jakarta: BPK. Gunung Mulia, 1991.

Bosch, David J., Trasformasi Misi Kristen Sejarah Teologi Misi Kristen Mengubah dan Berubah . Jakarta: BPK. Gunung Mulia, 1997.

Browlee, Malcolm. Pengambilan Keputusan Etis Dan Faktor-faktor Di Dalamnya, Cetakan Keenam .Jakarta: BPK. Gunung Mulia, 1991.

Depertemen Agama R.I. Direktorat Jenderal Bimbingan Masyarakat (Kristen) Protestan Proyek Peningkatan Pendidikan Agama 
Kristen DI Perguruan Tinggi. Penerapan Metode Kuantitatif Dalam Penelitian Gerejawi. Jakarta: Dirjen Bimas Kristen, 1997.

Dister, OMF, Nico Syukur. Kristologi Sebuah Sketsa Cet. Kedua Yogyakarta, 1988.

Drane, John, Memahami Perjanjian Baru Pengantar Historis Kritis . Jakarta: BPK. Gunung Mulia, 1996.

Drewes, B. F. Satu Injil Tiga Pekabar Cetakan ketiga. Jakarta: BPK. Gunung Mulia, 1989.

France, R.T., Yesus Sang Radikal . Jakarta: BPK. Gunung Mulia, 1996.

Halley, Henry H., Penuntun Ke Dalam Perjanjian - Baru . Surabaya: Yakin, 1979.

Heer, J. J. De.Tafsiran Alkitab Injil Matius I (fs. 1 s/d fs. 12). Jakarta: BPK. Gunung Mulia, 1982.

Hesselgrave, David J.. Mengkomunikasi Kristus Secara Lintas Budaya. Malang: Literatur SAAT. Cetakan Pertama, 2005.

Humas dan Protokol Sekretariat Daerah Kota Kupang. Sosok dan Pemikiran Bagi Kesejahteraan Rakyat: Drs. Daniel Adoe. Walikota Kupang 2007-2012. Kupang: CV. Karya Guna Kupang, 2011.

Hutapea, P., "Pengertian Tentang Dunia Dan Manusia Menurut Alkitab" Pendidikan Agama Kristen. Pemantang Siantar: Taman Pustaka Kristen,1994.

Johanis, Obertina Modesta. “Gereja Kaum (perempuan) Miskin”. Merentang Sejarah Memaknai Kemandirian Menjadi gereja bagi sesama oleh Majelis Sinode Gereja Kristen Pasundan. Jakarta: Mejelis Sinode Gereja Kristen Pasudan \& BPK. Gunung Mulia , 2009.

Kraybill, Donald B., Kerajaan Yang Sungsang . Jakarta: BPK. Gunung Mulia, 1993.

Kuiper, A. De, , Missiologia . Jakarta: BPK. Gunung Mulia, 1988.

Newman Jr., Barclay M. Kamus Yunani-Indonesia .Jakarta: BPK. Gunung Mulia, 1991.

R.T. France, Yesus Sang Radikal. Jakarta: BPK. Gunung Mulia, 1996),

Soedarmo, R. Iktisar Dogmatika .Jakarta: BPK Gunung Mulia, Cet. 51985.

Suryabrata, Sumadi Metodologi Penelitian Cet.6. Jakarta: Rajawali Pers, 1991.

Sudjarwo, H.. Metodologi Penelitian Sosial. Bandung: Mandar Maju, 2001.

Thiessen, Henry C., Theologia Sistematika. Malang: Gandum Mas, 1992.

Tim Keadilan, Perdamaian dan Ciptaan Dewan Gereja-gereja se-Dunia (DGD) Jenewa, 2006. Globalisasi Alternatif Mengutamakan Rakyat dan Bumi Sebuah Dokumen Latar belakang. Jakarta: PMK HKBP. Nd.

Tozer, A.W. Mengenal Yang Maha Kudus . Bandung: Kalam Hidup, nd. 
Yewangoe, A. Theologia Crusis Di Asia . Jakarta: BPK.Gunung Mulia, Cet. I, 1989.

\section{Majalah}

Alberdien. "Petugas Sosial Kecamatan (PSK) Dan Program Inpres Desa Tertinggal (IDT)”, Penyuluh Sosial No. 85 (Triwulan I/1994/1995)

Silalahi, W. N. Natsir “Gereja, Visi dan Missinya”. Refleksi No. 10 Desember 1989

Supardan. "Partisipasi Jemaat Dan Masyarakat Dalam Pembangunan Pada Dasa Warsa 90-an". Buletin Motivator 1, nd.

Koran

Kompas, Jumat 16 September 2011 , 175 juta hampir Miskin Pemerintah Pastikan Harga BBM Bersubsidi Tidak Naik

Kompas Jumat 16 September 2011, 46 Penyaluran anggaran Jangan politisasi dana kemiskinan

\section{Makalah}

Mesakh A.P Dethan, "Spiritualitas Hamba Tuhan" Orasi Ilmiah pada Dies Natalis dan Wisuda STTIK Kupang. 19 Agustus 2011.

\section{Wawancara}

Daniel Kaleraga, Wawancara Oleh Penulis, Kupang, Nusa Tenggara Timur tanggal 19 Juli 2012

Salmon Atamabi. Wawancara Oleh Penulis, Kupang, Nusa Tenggara Timur, 18 Juli 2012. 